$\begin{array}{ll} & \text { Etnográfica } \\ \text { etnográfica } & \text { Revista do Centro em Rede de Investigação em }\end{array}$

Antropologia

vol. $24(3) \mid 2020$

Vol. $24(3)$

\title{
Governing the house: an ethnographic approach (introduction)
}

\section{Benoît de L'Estoile and Federico Neiburg}

\section{(2) OpenEdition \\ Journals}

Electronic version

URL: https://journals.openedition.org/etnografica/9341

DOI: 10.4000/etnografica.9341

ISSN: 2182-2891

\section{Publisher}

Centro em Rede de Investigação em Antropologia

\section{Printed version}

Date of publication: 1 October 2020

Number of pages: 655-664

ISSN: 0873-6561

\section{Electronic reference}

Benoît de L'Estoile and Federico Neiburg, "Governing the house: an ethnographic approach

(introduction)", Etnográfica [Online], vol. 24 (3) | 2020, Online since 31 October 2020, connection on 20 January 2022. URL: http://journals.openedition.org/etnografica/9341 ; DOI: https://doi.org/10.4000/ etnografica.9341

Etnográfica is licensed under a Creative Commons Attribution-NonCommercial 4.0 International License. 


\section{Governing the house: an ethnographic approach (introduction)}

\section{Benoit de L'Estoile and Federico Neiburg}

L'ESTOILE, Benoît de (blestoile@gmail.com] - CNRS (CMH) ; Ecole normale supérieure/PSL, France.

NEIBURG, Federico (federico.neiburg@gmail.com) - Museu Nacional, Universidade Federal do Rio de Janeiro, Brasil.

THIS DOSSIER IS THE OUTCOME OF AN EXPERIMENT. WE CHALLENGED a group of scholars who have conducted long-term ethnographic research in various national settings (Brazil, Chile, France, Haiti, and Morocco) to take a new look at their material from the perspective of the government of the house.

This project was conceived long before the Covid-19 pandemic propelled the government of the house into a key issue in public debates and policies at a global scale. "Stay-at-home" (Fique em casa / Restez chez vous!) suddenly became a battle cry, formatting our collective lives and political confrontations concerning the right way to survive the pandemic. This ubiquitous motto translated into a vast array of often contradictory experiences: the house as a space for care or as a prison; a house for those privileged enough to settle in it, another for those ordered to stay home even if they need to go out in order to make a living; the house imagined as a peaceful nest or enacted as a setting for the domestic violence that accompanied confinement periods all over the world. ${ }^{1}$

The house has long been a privileged location for governing relations between humans and micro-organisms, whether through quarantines or through the new home management of the pandemic that we have been discussing and experiencing since the beginning of $2020 .^{2}$ The pandemic, however, brought into sharp theoretical and empirical focus the constitutive relation between houses and government, two notions generally treated separately but that, as

1 See for example < https://www.nejm.org/doi/full/10.1056/NEJMp2024046> (last consulted in October 2020).

2 See for example < https://apps.who.int/iris/handle/10665/33067l > (last consulted in October 2020). 
this dossier shows, are closely related. Houses have always been an object of government, in the form of sanitary, urbanistic and economic regulations, or through public and private housing policies. The statistical concepts of domicile or household, for example, are state devices for the government of the house which aim to define boundaries so as to stabilize dwellings and belongings. Efforts at governing houses have been especially prominent in colonial and post-colonial settings, where different government agents, from missionaries to colonial administrations to NGO's to international cooperation programs, have been active in projects to reform housing, all of which were integrally embedded in ideals of moral reform and the "development" of their inhabitants.

In our fieldwork, long before the pandemic, we found that governing the house was also of great concern to our interlocutors. In the Moroccan Atlas mountains, one of Pascal Mulet's interlocutors used a potent political metaphor to describe the rule of the house: "if my house were a State, my father would be the president"; another describes himself as a "king", implicitly comparing his house with the Moroccan kingdom. Such metaphors echo a long scholarly tradition of work on the Mediterranean house, revealing its unity and stressing its patriarchal dimension. They also resonate with the language of Aristotle in Politics, where he describes oikonomia, the master's rule over the oikos - which, in ancient Greek, included not only the house as building, but also the family (wife, children and slaves) and its patrimony -, as being of a "monarchic type", by contrast with the political rule of the magistrate in the polis, the city-state, over citizens conceived as equals. While oikonomia has often been translated as "administration of the house" or "domestic economy", Benoît de L'Estoile $(2014,2016)$, translates it as "government of the house", appropriating Foucault's polysemic understanding of "government", foregrounding it as a powerful heuristic device for a political approach to the house.

An attention to issues of power within the house has precedents, such as in Pierre Bourdieu's analysis of kinship among Bearn peasants, in the French Pyrenees. The Bearnese maison (maysou) refers not only to the house, but (as with oikos) also to the land possessed by the family. Bourdieu notes that the house was a sort of person, often having its own name, by means of which its inhabitants were identified. "In so far as he is the embodiment of the house, the capmaysoue, the head of the house, is the custodian of the name, the fame, and the interests of the group" (Bourdieu 1962:37). ${ }^{3}$ Conversely, the domestic group is embodied in the house. Bourdieu also paid attention to the tensions around power within the house: speaking of an authoritarian woman who tries to dominate her daughter in law, Bearnese peasants say that "the daune (the housemistress) ${ }^{4}$ doesn't want to let the ladle go".

4 Daune, master, is a Bearnese word etymologically related to dona in Portuguese and dueña in Spanish. 
Framing the question in terms of governing the house stresses issues of autonomy and freedom, power and domination, alliance and conflict, both in what pertains to the house taken as a unit of collective action in relation to the external world, and to that which exists within it, between its inhabitants. For many of our interlocutors in the field, these often appear as key concerns. Thus, the residents of Santiago de Chile met by Consuelo Araos insist that each house is governed by its own rules, defined by the masters of the house; an older man states that his wife "is still the mistress of the house (dueña de casa) here", contrasting his home to their experience of being guests in their children's houses: "You can even be better treated elsewhere, but it's not your own house". Similarly, Thomas Cortado's interlocutors in Rio de Janeiro's periphery express the need to be recognized as dominating (being dono) of one's plot and one's house, thereby valuing their "freedom". The Bushinengué women with whom Clémence Léobal did fieldwork associate the opportunity to move into a new "government house" with a sense of freedom.

The ethnographic approach of the government of the house that we present here is a product of various multilingual conversations (in the sense of Gudeman and Rivera 1990, and Neiburg 2019). Fieldwork was conducted in Chleuh, Haitian creole, Ndyuka, Portuguese and Spanish. During the last four years, seminars and workshops discussing these papers and others were held in different places in English, French, Portuguese and Spanish. From the outset, these multilingual conversations confronted us with the comparative nature of our project, with the dual existence of the house as a reference to singular buildings in our personal experience (as my home, or the house of my parents, etc.), and as the notion of house associated with various meanings, as shown by different terms like "house", "kay", "casa", "hogar", "jgua", "maison", "batiman", "cite", and their internal differentiations and hierarchies.

The Latin root terms that designate the house (maison, casa) refer both to the material aspects of the house, as a building, and to the people who live in it (in French, la maisonnée); they encompass the notions of "home" and "family", conflating affects and moral values, as in the expressions "se sentir em casa", "se sentir chez soi "or "to feel at home". As the Portuguese pun makes clear: "quem casa, quer casa" (literally "one who marries wants a house"), although obviously lost in translation, the verb casar in Spanish or Portuguese means, at the same time, to get married and to initiate a new domestic unit (home and family). When we use the term "house" in the following pages, the reader should therefore understand it in a wider sense than is usual in English, including both home and family. Thus, governing the house does not only refer to the control of the house as a physical and symbolic place, but also to the complex entanglements of power and affective relations among its inhabitants.

A recurring theme in social theory and public policy, the house has often been seen as a closed, self-contained unit, an intimate physical, moral and 
affective space isolated from others, inhabited by a nuclear family composed of a father, a mother and their children, all living under the authority of pater familias. This ideal model of the house, underpinned by a bourgeois ideal of the family associated with European modernity, has implicitly informed a good deal of the sociology of the family and of public housing policies (Bourdieu and Christin 1990). As described by Norbert Elias (1996 [1933]) in his classic survey of domicile types towards the end of the ancien régime in Europe, the bourgeois house projects onto space ideals of symmetry, comfort, solidity and stability that structure and reveal hierarchies and forms of authority. These forms of governing the house in turn structure the house itself as a physical and moral space isolated from others, according to the ideal of the house as a dwelling for the "nuclear family". Ethnographic and historical studies however offer a different picture. In fact, as the articles in this dossier show, houses are never isolated, but always in process and in relation, forming changing networks and configurations.

Personal and collective relations among persons and houses include those who belong to the house and those who are not there, as well as those who are in movement, in the landscapes of diasporas. Houses are always part of configurations and networks of houses that develop at various scales; they can involve their immediate vicinity (Pina-Cabral 2019), the neighbourhood, the close kin. Following migration routes, they can also extend over borders, such as between French Guyana and Surinam, or the complex networks relating Haiti to France, French Guyana and Brazil, studied by Handerson Joseph.

Houses are hierarchically structured material and moral spaces. The house is at once a place of proximity, a shelter from the world outside, and a place of danger and inequality. Houses and persons are co-constitutive. Both exist in time, are born, develop, transform, and die. Like persons, houses are morally charged, or are seen as moral agents which act on persons. As Eugênia Motta suggests in her article, houses can be morally judged as "good" or "bad", and their morality is intrinsically linked to the one of the persons who live in them. In that respect, the government of the house emerges as a complex universe peopled by agents and agencies of different scales, inside and outside doors.

$$
\text { * } *
$$

Houses entered Western imagination and anthropology under the heading of "material culture". Starting in the $19^{\text {th }}$ century, ethnographic museums typically featured dwellings of the Other deemed to be "picturesque" and distinct from Western European patterns, such as the North American Prairie tipis, 
Inuit igloos, Mongolian yurts, Amazonian malocas, African huts, etc. The first open-air museum, inaugurated in Skansen in 1891, aimed to display Sweden in miniature, with houses being brought in from every rural part of the country. Material and architectonic aspects gained prominence in such displays, often tainted by a romanticized view of the house. Accordingly, houses were also the focus of earlier ethnography. In the classical works of the discipline, anthropologists approached the house as part of their ethnographic brief to record in detail the variety of villages and forms of dwelling, producing a rich documentation. While the house was also present in ethnographies as a background in studies of kinship and family, for long seen to be the core of the discipline, it acquired centrality as an object of investigation in later works, such as those of Pierre Bourdieu (1962, 1970), Mary Douglas (1991), Claude Lévi-Strauss (1991), or Janet Carsten and Stephen Hugh-Jones (1995). In a classic study, Bourdieu (1970) described the maison kabyle as a microcosmos of Kabyle cosmology and social structure, hierarchized by gender and seniority. Douglas investigated the home as a special kind of moral and physical place, at the same time an archival machine that keeps memories alive and serves as a space for the relationships between humans and more-than-human beings. Lévi-Strauss, using a French legal term, stated that the house is an "institution" (personne morale), which transcends and survives the successive generations of its members, and described "house societies" as much more flexible and fluid than those organized through the binary principles of descent and affinity. Explicitly drawing on Lévi-Strauss, Carsten and Hugh-Jones provided the first comparative set of researches to take the house as a point of entry for ethnography but with a restricted comparative scope, they left out Western/ " "modern" houses and societies.

Our collective project was rooted not only in anthropological traditions of research in Europe and the us, but also in the Brazilian tradition for which the great divide between our and other houses was irrelevant. From the early 1970's on, Brazilian anthropology looked at the house in innovative ways. In the rural spaces of the Brazilian Northeast, for example, the relationship between houses, agricultural work and forms of domination was at the centre of ethnographic researches on the post-plantation (e.g., Palmeira 1977 and Heredia 1979). In urban settings, Woortman (1982) and Machado da Silva (2018 [1979]) took the house as a privileged vantage point from which to study the lives of the working class and the urban poor in the favelas, breaking with the paradigm of anomia and dysfunctionality associated with matri-centered families. Building on these traditions, Louis Herns Marcelin's study of afro-descendants in Bahia proposed the concept of a "configuration of houses" (1999), while Pina-Cabral and Godoi (2014) wrote of the house as a "place for life". This dossier is an outcome of a collective and transnational research project, "Modes de Gouvernement et Pratiques Economiques 
Ordinaires", 5 which became a hub for this new anthropology of the house that is at present expanding in our discipline. Among other results, the project has produced an abundant literature on houses and ways of dwelling (among others, e. g. Motta 2014, Cortado 2020, Araos 2016, Léobal 2016, Guedes 2017, Dalmaso 2018, García de Teresa 2019), emerging from a set of ethnographic researches that have been developed in dialogue, within a comparative framework, and a set of common references.

$$
\text { * } *
$$

The six ethnographically rich and theoretically creative articles that follow explore the government of the house in its various dimensions and scales.

Thomas Cortado, studying the aesthetics and politics of walls in a working-class self-construction area in the distant periphery of Rio de Janeiro, shows how residents are putting a lot of money and effort to physically "close up" their house by adding fences, walls, and sometimes transforming them into "fortresses". Cortado brings into light what he calls the "geopolitics of privacy": residents equate privacy with freedom, which they define as the ability to follow one's own rules by not being dependent on one's neighbours or relatives. Therefore, putting up walls so that each house has its own entrance allows for freedom, securing the control of the family and its movement. It is essential to reveal to others that one is effectively governing one's house, "taking care" of it, by occupying the space, especially constructing fences. A plot left empty is considered "unoccupied", without a master, and therefore up for grabs. Construction is not only directed towards the residents of the house, but is also a sign directed at their neighbours: walls are not only isolating and separating, but are also a mode of relating.

Studying two contrastive family arrangements among Berber peasant families in the Atlas Mountains of Morocco, Mulet questions the self-evident character of the "domestic unit", which assumes the unity of the house idealized as a form of "domestic community", embodied by its male head. For Mulet, the underlying reality is economic: what he terms the "exploitation agropastorale", an agropastoral venture which he defines as a "non-exclusive unit of production and consumption formed around the exploitation of a patrimony". Looking at the actual fluxes of money, he exposes the fictitious character of the patriarchal community, and exposes the daily work necessary to "make a house", 
a continuous process of constructing a "fiction of unity", both in discourse and in practices.

Clémence Léobal has studied the ways Bushinengué inhabitants in Saint Laurent du Maroni (Soolan in Saamaka), in French Guyana, variously resist, accommodate, negotiate, and appropriate the urban removal and housing policies of the French State in this overseas territory. Paying close attention to the material aspects, she shows how residents appropriate these "government houses" by transforming their external and internal spaces, making them progressively "their own house". Many of them (specifically women) make known their satisfaction at being "free" (frey) when they get access to their new "homes". Léobal explores the meanings of this feeling of "freedom" in relation to one's relatives and to marriage: in a polygamous context, having access to one's own house affords new opportunities of autonomy for women in relation to their male partners, whereas in self-constructed detached houses the male role in constructing and maintaining the house was central. Léobal reminds us of the need to consider the government of the house at various scales.

Araos studies daily movements between the houses of closely related nuclear middle- and upper middle-class families in Santiago (Chile). Instead of approaching the circulation between houses in an objectivist manner, as statistical "facts", she instead interprets them as "gestures", that is, as acts endowed with meanings, affects and moral evaluations. She shows the work of care involved in "making a home" (haciendo hogar) and how care can be experienced as a form of pressure and may even become a burden. This allows her to highlight various "modes of government" of relations between close kin. Asymmetries of movement and care end up producing "incomplete houses", occupying a subordinate place within the network, generating tensions.

In Haiti, Joseph describes what his interlocutors call kay diaspora (diaspora houses), which are strikingly different from kay local (local houses), both by their architecture (for instance, including "western" bathroom, toilets and kitchen) and the presence of imported appliances and furniture. However, these diaspora houses are in fact closely linked to a "local house", and are sometimes part of the same residential unit, which is usually inhabited by close kin, between whom there is an uninterrupted flow of money and goods. The process of building and maintaining diaspora houses thus reveals a combination of government at a distance and daily government by local kin.

Eugênia Motta starts from a reflection on the illness and subsequent death of a friend she made during her fieldwork in one of Rio de Janeiro's numerous favelas. Her fine-grained ethnography, which is also a subtle form of mourning, allows us to understand how affects and moralities are woven into daily practices within the house. Studying the circulation of money, things, people and care between houses in the favela, Motta (2014) has shown that the relationship of care, which is constitutive of the house, implies an asymmetry between 
those who care and those who are cared for. In this issue, Motta highlights the existence of "hierarchies of care" that develop between different houses, defining a more central house within a network of care. Motta powerfully reminds us that, along with the question of government (who is ruling whom?), the question of care (who is caring for whom?), and the hierarchies it establishes and reproduces, is central to the constitution of the house and its inhabitants as persons.

More generally, the government of the house is not only about domestic sovereignty (who is recognized as head of the house) but also involves the government of daily life: who makes decisions such as whom to invite to the house for coffee, lunch, or sleeping over? Who defines how resources are spent, for the house or for its inhabitants, human or nonhuman? Being highly gendered spaces, houses bring into evidence the gendered nature of the ethnographic relationship (and vice versa). The ways in which ethnographers enter houses and share sociabilities is necessarily informed by gender (Carsten 2012). The articles in this issue are authored by an equal number of men and women ethnographers. While some authors emphasize issues of care and commensality, underlining the authority of women within the house, others emphasize male authority and the more explicitly political dimensions of the government of the house. However, whether prioritizing one or another aspect, all underline the relationality and asymmetries of genders that make houses and persons.

Breaking with an objectivist approach to the house, observing it from the outside, so to speak, houses are here described "from within", a move made possible by long-term fieldwork, allowing ethnographers to share the lives of those who inhabit houses. However, this perspective from within does not imply that houses are unitary or homogeneous. Depending on which members of the house, or configuration of houses, the ethnographer chooses to focus on, the house might be described as a singular blend of freedom and domination.

The various ethnographic approaches to governing the house that are brought together in this dossier therefore bring to light movements, alliances and conflicts that occur within the house, between houses, and among different scales that overlap while making houses. Maintaining the material existence and autonomy of the house is a challenge, especially in the face of such formidable threats as the French State's policies of removing precarious habitations in Saint Laurent du Maroni, or the gangs controlling drug traffic or militias in Rio de Janeiro. The articles show the constitutive tensions between the quest for the ideal of autonomy and the necessary interdependence which is a condition for the existence of the house and persons - persons who inhabit houses and houses that inhabit persons. 


\section{REFERENCES}

ARAOS, Consuelo, 2016, "When family lives nearby: kinship, socioeconomic conditions and residential configurations in Santiago, Chile", Cuadernos ISUC, l (1): 1-18.

BOURDieu, Pierre, 1962, «Célibat et condition paysanne », Etudes Rurales, 5/6 : 32-136.

BOURDIEU, Pierre, 1970, "The Berber house or the world reversed", Social Science Information, 9 (2): 151-170.

BOURDIEU, Pierre, and Rosine CHRISTIN, 1990, « La construction du marché : le champ administratif et la production de la "politique du logement" », Actes de la Recherche en Sciences Sociales, 81-82: 65-85

CARSTEN, Janet, 2012, "Fieldwork since the 1980s: total immersion and its discontents", in The Sage Handbook of Social Anthropology, available at < http://dx.doi.org/10.4135/978 1446201077.n36 > (last consulted in October 2020).

CARSTEN, Janet, and Stephen HUGH-JONES, 1995, About the House: Lévi-Strauss and Beyond. Cambridge, Cambridge University Press.

CORTADO, Thomas Jacques, 2020, « Maison », Anthropen. Paris, Editions des Archives Contemporaines. DOI: https://doi.org/10.17184/eac.anthropen.131.

DALMASO, Flávia, 2018, "Heranças de família: terras, pessoas e espíritos no sul do Haiti", Mana, 24 (3): 96-123.

DOUGLAS, Mary, 1991, “The idea of a home: a kind of space”, Social Research, 58 (1): 287 $-307$.

ELIAS, Norbert, 1996 [1933], The Court Society. London, Basil Blackwell.

GARCÍA DE TERESA, Marcos, 2019, Transactions Identitaires : Champignons et Chevaux dans la Sierra Mazateca (Mexique), doctoral thesis in social anthropology and ethnology.

GUDEMAN, Stephen, and Alberto RIVERA, 1990, Conversations in Colombia: The Domestic Economy in Life and Text. Cambridge, Cambridge University Press.

GUEDES, André Dumas, 2017, "Construindo e estabilizando cidades, casas e pessoas", Mana, 23 (3): 403-435.

HEREDIA, Beatriz, 1979, A Morada da Vida: Trabalho Familiar de Pequenos Produtores do Nordeste do Brasil. Rio de Janeiro, Zahar.

LEOBAL, Clémence, 2016, «Des marches pour un logement : Demandeuses bushinenguées et administrations bakaa », Politix, 16 (4): 163-192.

L'ESTOILE, Benoît de, 2014, "Money is good, but a friend is better: uncertainty, orientation to the future, and the economy", Current Anthropology, 55 (9): 62-73.

L'ESTOILE, Benoît de, 2016, “Oikonomia or governing the house: state policies, domestic practices and 'worthy life' in Northeastern Brazil", paper presented at the panel "Oikonomia, The government of the house, 'life' and 'the good life'", EASA conference, Milan.

LEVI-STRAUSS, Claude, 1991, « Maison », in Michel Izard and Pierre Bonte (eds.), Dictionnaire de l'Ethnologie et de l'Athropologie. Paris, Presses Universitaires de France, 434-436.

MARCELIN, Louis Herns, 1999, "A linguagem da casa entre os negros do Recôncavo Baiano”, Mana, 5 (2): 31-60.

MOTTA, Eugênia, 2014, "Houses and economy in the favela", Vibrant - Virtual Brazilian Anthropology, 11 (1): 118-158.

NEIBURG, Federico, 2019, "Entrando na conversa", in Federico Neiburg (ed.), Conversas Etnográficas Haitianas. Rio de Janeiro, Papéis Selvagens, 13-24. 
PALMEIRA, Moacir, 1977, "Casa e trabalho: nota sobre as relações sociais na plantation tradicional”, Contraponto, 2: 103-114.

PINA-CABRAL, João de, 2019, "Partible houses: variants of vicinage in Mozambique, Portugal and Brazil", Journal of Urban Research, 20, available at < https:/doi.org/10.4000/artic ulo.4434 > (last consulted in October 2020).

PINA-CABRAL, João de, and Emília Pietrafesa de GODOI, 2014, "Apresentação: dossiê vicinalidades e casas partíveis", Revista de Antropologia, 57 (2): 11 -21.

SILVA, Luiz Antonio Machado da, 2018 [1979], "A oposição entre o trabalho doméstico e o trabalho feminino remunerado", in Luiz Antonio Machado da Silva, Mariana Cavalcanti, Eugênia Motta and Marcella Araujo (eds.), O Mundo Popular: Trabalho e Condições de Vida. Rio de Janeiro, Papéis Selvagens, 29-44.

WOORTMANN, Klas, 1982, “Casa e família operária”, Anuário Antropológico, 8: 119-150. 